\title{
"But that is your opinion": the dark side of postmodern pain medicine creating a postmodern patient autonomy
}

This article was published in the following Dove Press journal: Journal of Pain Research

\author{
Jan M Keppel Hesselink' \\ Michael E Schatman ${ }^{2,3}$ \\ 'Institute for Neuropathic Pain, Bosch \\ en Duin, the Netherlands; ${ }^{2}$ Boston \\ Pain Care, Research and Network \\ Development Waltham, MA, USA; \\ ${ }^{3}$ Department of Public Health and \\ Community Medicine, Tufts University \\ School of Medicine, Boston, MA, USA
}

Correspondence: Jan M Keppel Hesselink Institute for Neuropathic Pain, Spoorlaan 2a, 3735 MV Bosch en Duin, the Netherlands

Tel +3I $65 \quad 1700527$

Email neuropathie7@gmail.com
"But that is your opinion", our patients tell us. They make this remark following our explanations that if they want natural remedies for their sleep disorders, cannabis oil is not the best choice, and that L-theanine is probably a better choice. We point out the various problems one can face when using cannabis oil regularly for treating sleep disorders and explain that although we may prescribe medical cannabis for certain conditions, we do not do so for sleep disorders due to the fact that cannabis might not be the first choice for this indication. ${ }^{1}$ Patients shrug their shoulders and say, "That again is your opinion, a friend of mine is using cannabis oil and is very happy with it". End of discussion. They want prescriptions/authorizations for cannabis oil. What are we to do? Are we obliged to correct what we believe is erroneous thinking or do we emphasize respect for patient autonomy and allow what we perceive to constitute irrationality dominate our clinical judgment and decision making?

It will not go unnoticed to many colleagues that increasingly patients come to see health care providers having already prepared their own agendas regarding diagnosis and treatment. These agendas are often based on Google searches. Our patients tell us, "Doctor, I have become a PhD in Google-search, and here are my findings". Recently we have seen coffee-mugs inscribed with: "Do not mistake your Google-search with my medical degree", although we doubt putting these cups on our desks will be productive. Patients themselves might be convinced, for example, that they are suffering from "chronic Lyme" and want us to prescribe lengthy courses of antibiotics. If a physician asks whether a patient has been bitten by a tick, experienced an erythema migrans, and underwent diagnostic testing, the answer of the patient might be: "I think I have been bitten, but I did not see any red circles on my skin. I understood that does not necessarily mean that I'm not infected. Just as the tests you are proposing do not exclude that I have been infected if they are negative. So, I just want to be treated with antibiotics, to be sure. That is my opinion..." Now the dilemma is complete. Providers often feel ill-equipped to counteract this last argument directly, while patients feel they have become experts regarding their own illnesses, and that the dialogue with their physician is stagnant.

Such cases are intensely debated by sociologists and philosophers within the context of postmodern medicine. One might, however, not be aware of this phenomenon. A PubMed search utilizing the combination of keywords "postmodern" and "medicine" 
will generate only 161 hits, among which only nine include the words "postmodern" and "medicine" in the title. However, there is an increasing following of postmodern thinking, and such thinking is increasingly colliding with our own clinical judgment. In order to constructively react to this tendency in our society we need first to understand the key issues of postmodern medicine and its philosophy.

In the context of the International Association for the Study of Pain's (IASP's) 2018 “Global Year for Excellence in Pain Education", Daniel Carr published a paper on postmodern pain education. ${ }^{2}$ To our knowledge, this is the first paper linking postmodern thinking to the topic of pain. The author stipulated that modern pain education is shifting from "conveying impersonal, objective evidence at the scale of nociceptors or subcellular processes towards greater inclusivity of multiple types of knowledge, attitudes, and experience including patient narratives, skepticism towards the utility of objective evidence in the absence of context" (p. S49). Carr noted that randomized controlled trials (RCTs) have failed to eliminate uncertainty regarding what constitutes the best treatment for each patient in each case. He then discussed the "inconvenient truth" that evidence-based medicine has failed to simplify everyday clinical decision making, and rather has resulted in "complexification" of the evidence collection process. In order to elucidate further the impact of postmodern thinking on pain management, we will discuss aspects of postmodern thinking related to daily practice and also highlight some of postmodern pain medicine's “dark sides".

\section{Postmodern pain medicine and its philosophy}

Many of the current debates in pain medicine, such as the role of complementary and alternative medicine, can be analyzed from the perspective of postmodern philosophical views on medicine. In postmodern pain medicine, all voices are equally important, which is consistent with the opinions of postmodern philosophers. Some of the contemporary thinkers of postmodern philosophy who support absolute equality of ideas include Thomas Kuhn, Mikhail Mikhailovich Bakhtin, Jacques Derrida, Paul-Michel Foucault and Jean-François Lyotard. It is telling that none of these thinkers is a physician; postmodern medicine is (paradoxically) defined by non-medics.

One of the most important concepts in postmodern medicine is the "grand narrative" or "meta-narrative" and the "narrative", concepts introduced by the French philosopher Lyotard in his 1979 essay, "The Postmodern Condition: A
Report on Knowledge" ("La condition postmoderne: rapport sur le savoir"). ${ }^{3}$ A narrative is the subjective story of any storyteller (for instance the patient), and the meta- or grand-narrative can be equated as the concepts supported by science, the "truth" of medical textbooks, guidelines, and meta-analyses. For example, the narrative of a patient may be: "Medical marijuana is beneficial for chronic pain patients, as it's natural". The (competing) meta-narrative in this example would be: "Based on the most recent studies, medical marijuana is neither safe nor particularly effective". In postmodern pain medicine, the opinion of the patient has become as "valid" as the empirical data, and when available, systematic reviews and meta-analyses. Lyotard went one step further by supporting the end of grand narratives or meta-narratives, and defined postmodernism as incredulity toward these meta-narratives. A personal story thus has at least the same value and right to be considered as valid as an entire collection of scientific papers, a medical textbook or meta-analyses. "Science is nothing more than one narrative among many", according to the oncologist David Gorsky in his blog, "Postmodernist attacks on science-based medicine". Now all of this philosophy might be nothing more than a collection of idle, and definitely not practical ideas, many would think. However, in line with this philosophy and the impact of the Internet, one individual voice or one narrative today will become a chorus tomorrow. Videos on unproven pain treatments go viral on YouTube, Facebook and Instagram. Many patients find themselves united via Facebook and Twitter groups, and an entire subculture is emerging outside of the awareness of many. This subculture is mostly, if not entirely, based on personal experience, and sometimes fed by irrational fears that can become strong and emotionally fueled opinions. From symbolic convergence theory, we have learned that individuals with a common goal who are not familiar with each other can quickly form a cohesive group via exchange of emotional stories. This is what happens, for example, on Facebook and Twitter relating to many issues, such as medical marijuana and kratom as " $100 \%$ safe and effective" treatments for chronic pain. That numerous studies and reviews published this calendar year ${ }^{5-17}$ have further elucidated safety issues associated with marijuana use and the United States Food and Drug Administration (FDA) has issued warnings regarding kratom's safety ${ }^{18}$ seem to fall on deaf ears among patients seemingly deluding themselves. In postmodern pain medicine, the interpretation of these data by pain scientist-practitioners has apparently become less relevant. 


\section{Chronic pain treatment: paralogical treatments and opioids}

In pain medicine, there are useless or detrimental treatments that are advocated based on personal experience, as well as useful treatments that are maligned as toxic approaches without evidence supporting doing such. An example of such a sham is the alkaline diet, which has been recommended on the Internet as a cure for arthritis, chronic pain, obesity, and cancer. One can even find sites recommending drinking baking soda, ${ }^{19}$ which is not only odd but will increase one's sodium load and thus may have opposite health effects as those for which a naïve individual may hope. It has been established that consumption of baking soda is not going to change the $\mathrm{pH}$ of the blood, due to the capacity of our buffer system, and the pulmonary and renal compensation systems. If alkaline diets help reduce pain, it is due to other factors and not due to alkalization of the blood. ${ }^{20,21}$ However, on the Internet there appear many stories of patients supporting consumption of baking soda as a remedy for pain and other symptoms and disorders, supported by non-rational, paralogical thoughts on the mechanism of action of such treatment. The same irrational arguments and supportive case stories may be found to malign opioid therapy (or any other product synthesized by the pharmaceutical industry) for chronic pain. These arguments are often magnified by journalists, who also have tended to follow the postmodern principle of "everyone's opinion is equal". ${ }^{22}$

Consider the impact of postmodern pain medicine on the wildly swinging American opioid pendulum. Long considered the treatment of choice for severe acute pain, the late 1990s witnessed a rapid shift in the United States from avoidance of opioid analgesics in the treatment of chronic pain of non-malignant origin to a climate of indiscriminate prescribing. This shift was due to a number of factors, including fraudulent marketing, the liberalization of standards for prescribing opioids to patients with non-cancer pain by state medical boards, revised standards for pain management instituted by the Joint Commission on Accreditation of Healthcare Organizations (JCAHO), and the advocacy of increased opioid prescription by certain physicians and organizations. ${ }^{23}$ The shift to opioids for non-cancer pain was based on weak evidence and was heavily influenced by the opinions of Russell Portenoy. ${ }^{24,25}$ Despite being one of the key opinion leaders in regard to cancer pain management, Portenoy's support for the use of opioids for non-malignant pain is a prime example of postmodern pain medicine, as his opinion was not empirically supported, and he was not an expert in non-cancer pain management. Unfortunately, postmodern pain medicine has reared its ugly head once again to create and support the recent American climate of opiophobia. For example, reviews and guidelines emphasize "opioid-induced hyperalgesia" as a reason not to prescribe. ${ }^{26}$ Opioid-induced hyperalgesia, however, is a concept based on experimental neurophysiological models, with clinical evidence for such a phenomenon still lacking. ${ }^{27}$ Furthermore, recent guidelines regarding opioid prescribing are anything other than scientific - with strong opinions supported by individual stories, non-scientific agendas, and frank deceit dominant. $^{28}$

\section{Restoration: rebuilding patients' autonomy based on transparency, the fact box}

As providers who treat pain, we need first to understand the tremendous force of postmodern pain medicine, as it has the potential to undermine rational practice. While accepting the importance of respecting patients' phenomenological experiences of their illnesses, clinicians are still the experts when it comes to diagnosis and treatment. It will not be easy to find solutions allowing us to continue constructive communications with patients in this postmodern world, one in which grand narratives are eroding into "just an opinion". However, there is an imperative to do so, and we will now present a concept for a balanced and rational strategy to create a better fundament for patients' autonomy than the above-mentioned extremes of postmodern pain medicine.

Mutual trust is an important lubricant in contemporary society, and thus also for the context of our work in pain management. To support such trust, patients need to feel that doctors and medical institutions present relevant medical information in a most transparent manner. This can be done in a variety of ways, and we present here the method of the fact box, as introduced by Gerd Gigerenzer ${ }^{29}$ in an editorial published in the British Medical Journal. A nice example of the construction of a "fact box" is illustrated through discussion of the pros and cons of mammography. The fact box helps deal with uncertainties while making medical decisions within the patient-doctor dyad and creates a maximum of transparency by building upon answers to frequently asked questions. A simple matrix, the fact box can visualize the effects of interventions. In such a fact box we can find clear answers on straightforward questions under the headers "Benefits" and "Harms". For example, a key question related to benefits - how many women died from breast cancer in 1,000 women in a period of 10 years with (4) and without (5) screening, and related 
to harms - how many women experienced false alarms or biopsies: none in the not-screened population and 50-200 in the screened population.

Such information is transparent and can subsequently be the base for a joint decision regarding mammography, without the patient feeling overwhelmed and pushed by her clinician. This is only possible if the information presented to the patient is introduced in a comprehensible form. Of course, the patient has the last word, and there is room for personal preferences in weighing the pros and cons. Irrespective, clinicians should strive to do everything possible to ensure that the assessment is made based on available scientific facts.

Patients with pain are constantly looking for answers that exclude uncertainties. Both in formal medical training and in-service training, it is accordingly important to learn to cope with the uncertainties of pain medicine in general and those of each patient. The example of the fact box provides a strong basis for clear communication regarding scientific facts, and while it pertains to oncology, there is no reason why it cannot be applied to pain practice.

This is the only rational solution we have developed within the context of the "crisis of faith" in pain medicine as presented by postmodernism. We expect that many patients would feel supported by such an approach. However, there will always be a group of extremists who will continue to use container opinions and posit that all medications are shams, all complementary and alternative approaches are universally successful, and unproven substances such as marijuana and kratom are safe - irrespective of the accuracy of medical facts that are presented. Ideally, we will "cure" postmodern pain medicine; however, doing so will likely be impossible ... and we will have to be content with encouraging a shared decision making model that will simultaneously increase patient autonomy while improving clinical outcomes.

\section{Disclosure}

Michael E Schatman serves as a consultant to Kaleo. The other author reports no conflicts of interest in this work.

\section{References}

1. Garcia AN, Salloum IM. Polysomnographic sleep disturbances in nicotine, caffeine, alcohol, cocaine, opioid, and cannabis use: A focused review. Am J Addict. 2015;24(7):590-598.

2. Carr DB. Postmodern pain education: "from being to becoming". Pain. 2018;59(Supp1 1):S49-S55.

3. Lyotard J-F. The Postmodern Condition: A Report on Knowledge. La condition postmoderne: rapport sur le savoir. Paris: Minuit; 1979.
4. Gorsky D [webpage on the Internet]. Postmodernist attacks on science-based medicine. Science-Based Medicine, September 15, 2008. Available from: https://sciencebasedmedicine.org/postmodernistattacks-on-science-based-medicine/. Accessed September 23, 2018.

5. Leb JS, D’Souza B, Steiner RM. Marijuana Lung. Chronic Obstr Pulm Dis. 2018;5(1):81-83.

6. Kalla A, Krishnamoorthy PM, Gopalakrishnan A, Figueredo VM. Cannabis use predicts risks of heart failure and cerebrovascular accidents: results from the national inpatient sample. J Cardiovasc Med (Hagerstown). 2018;19(9):480-484.

7. Henriquez JE, Rizzo MD, Crawford RB, Gulick P, Kaminski NE. Interferon- $\alpha$-mediated activation of $\mathrm{T}$ cells from healthy and HIVinfected individuals is suppressed by $\Delta 9$-tetrahydrocannabinol. $J$ Pharmacol Exp Ther. 2018;367(1):49-58.

8. Nourbakhsh M, Miller A, Gofton J, Jones G, Adeagbo B. Cannabinoid hyperemesis syndrome: reports of fatal cases. J Forensic Sci. Epub 2018 May 16.

9. Khashaba E, El-Helaly M, El-Gilany AH, Motawei SM, Foda S. Risk factors for non-fatal occupational injuries among construction workers: A case-control study. Toxicol Ind Health. 2018;34(2):83-90.

10. Davis AK, Walton MA, Bohnert KM, Bourque C, Ilgen MA. Factors associated with alcohol consumption among medical cannabis patients with chronic pain. Addict Behav. 2018;77:166-171.

11. Choi NG, Marti CN, DiNitto DM, Choi BY. Older adults' marijuana use, injuries, and emergency department visits. Am J Drug Alcohol Abuse. 2018;44(2):215-223.

12. Coleman-Cowger VH, Oga EA, Peters EN, Mark K. Prevalence and associated birth outcomes of co-use of Cannabis and tobacco cigarettes during pregnancy. Neurotoxicol Teratol. 2018;68:84-90.

13. Rabin RA, Kozak K, Zakzanis KK, Remington G, George TP. Effects of extended cannabis abstinence on clinical symptoms in cannabis dependent schizophrenia patients versus e non-psychiatric controls. Schizophr Res. 2018;194:55-61.

14. Moulin V, Baumann P, Gholamrezaee M, et al. Cannabis, a significant risk factor for violent behavior in the early phase psychosis. Two patterns of interaction of factors increase the risk of violent behavior: cannabis use disorder and impulsivity; cannabis use disorder, lack of insight and treatment adherence. Front Psychiatry. 2018;9:294.

15. Rineer JR, Duhart Clarke S, Cluff LA, Peiper NC. Comparing medical and recreational cannabis use among employees: associations with health and work-related outcomes. Int Rev Psychiatry. 2018;30(3):268-276.

16. Mikulskaya E, Martin FH. Contrast sensitivity and motion discrimination in cannabis users. Psychopharmacology (Berl). Epub 2018 Jun 16.

17. Micallef J, Dupouey J, Jouve E, et al. Cannabis smoking impairs driving performance on the simulator and real driving: a randomized, double-blind, placebo-controlled, crossover trial. Fundam Clin Pharmacol. 2018;32(5):558-570.

18. US Food and Drug Administration [webpage on the Internet]. Statement from FDA Commissioner Scott Gottlieb, M.D., on the agency's scientific evidence on the presence of opioid compounds in kratom, underscoring its potential for abuse; 2018. Available from: https://www. fda.gov/newsevents/newsroom/pressannouncements/ucm595622.htm. Accessed September 22, 2018.

19. MD-Health.com [webpage on the Internet]. Drinking baking soda for your health. Available from: http://www.md-health.com/DrinkingBaking-Soda.html. Accessed September 23, 2018.

20. Schwalfenberg GK. The alkaline diet: is there evidence that an alkaline pH diet benefits health? J Environ Public Health. 2012;2012:727630.

21. Hietavala EM, Puurtinen R, Kainulainen H, Mero AA. Low-protein vegetarian diet does not have a short-term effect on blood acid-base status but raises oxygen consumption during submaximal cycling. $J$ Int Soc Sports Nutr. 2012;9(1):50.

22. Schatman ME. The American chronic pain crisis and the media: about time to get it right? J Pain Res. 2015;8:885-887.

23. Manchikanti L, Fellows B, Ailinani H, Pampati V. Therapeutic use, abuse, and nonmedical use of opioids: a ten-year perspective. Pain Physician. 2010;13(5):401-435. 
24. Portenoy RK, Foley KM. Chronic use of opioid analgesics in nonmalignant pain: report of 38 cases. Pain. 1986;25(2):171-186.

25. Portenoy RK. Opioid therapy for chronic nonmalignant pain: a review of the critical issues. J Pain Symptom Manage. 1996;11(4):203-217.

26. Manchikanti L, Vallejo R, Manchikanti KN, Benyamin RM, Datta S, Christo PJ. Effectiveness of long-term opioid therapy for chronic noncancer pain. Pain Physician. 2011;14(2):E133-E156.

27. Eisenberg E, Suzan E, Pud D. Opioid-induced hyperalgesia (OIH): a real clinical problem or just an experimental phenomenon? J Pain Symptom Manage. 2015;49(3):632-636.
28. Washington State Agency Medical Directors' Group (AMDG) in collaboration with an expert advisory panel, actively practicing providers, public stakeholders, and senior state officials. Interagency Guideline on Prescribing Opioids for Pain; 2015. Available from: http://www. agencymeddirectors.wa.gov/Files/2015AMDGOpioidGuideline.pdf. Accessed September 23, 2018.

29. Gigerenzer G. Full disclosure about cancer screening. BMJ. 2016;352:h6967.

Dove Medical Press encourages responsible, free and frank academic debate. The content of the Journal of Pain Research 'Editorial' section does not necessarily represent the views of Dove Medical Press, its officers, agents, employees, related entities or the Journal of Pain Research editors. While all reasonable steps have been taken to confirm the content of each Editorial, Dove Medical Press accepts no liability in respect of the content of any Editorial, nor is it responsible for the content and accuracy of any Editorial.

\section{Journal of Pain Research}

\section{Publish your work in this journal}

The Journal of Pain Research is an international, peer reviewed, open access, online journal that welcomes laboratory and clinical findings in the fields of pain research and the prevention and management of pain. Original research, reviews, symposium reports, hypothesis formation and commentaries are all considered for publication
The manuscript management system is completely online and includes a very quick and fair peer-review system, which is all easy to use. Visit http://www.dovepress.com/testimonials.php to read real quotes from published authors. 